\title{
PRAE-MENDELISTISCHE ERFELIJKHEIDSTHEORIEËN
}

\author{
door M. J. Sirks.
}

Als onderdeel der biologie is de erfelijkheidsleer afstammeling van de physiologie, van de onderzoeksrichting, die de levensverschijnselen van planten en dieren waarneemt, en wel speciaal van de voortplantingsphysiologie. Uit haar opvattingen zijn dan ook de eerste ideeën over erfelijkheid voortgekomen; de revoluties en evoluties, die de voortplantings- en bevruchtingsleer heeft doorgemaakt, zijn ook schokken en keerpunten in de ontwikkeling der erfelijkheidsleer geweest. Zoo vinden we iñ beide wetenschappen een evenwijdigen ontwikkelingsgang; de scherpe tegenstelling tusschen praeformatistische en epigenetische theorieën, die vooral in LEEUWENHOEK's tijd in de voortplantingsleer zoo op den voorgrond stond, dan weer teruggedrongen schijnt en telkens weer met nieuwe kracht omhoog komt, diezelfde scherpe tegenstelling kunnen we, zij het in eenigszins anderen vorm, als roode draad door alle erfelijkheidsopvattingen in den loop der eeuwen heen vervolgen.

In de physiologie der bevruchting hebben eeuwen lang voorstanders der beide richtingen elkaar bestreden. Praeformatisten meenden in de stoffen, waaraan na de berruchting het nieuwe organisme zijn ontstaan dankte, reeds alle organen en alle deelen van dit nieuwe organisme van te voren gevormd, gepraeformeerd, te mogen zien, zoodat de geheele ontwikkeling na het moment der bevruchting een werkelijke „ontwikkeling”, een evolutie, een ontplooiïng van reeds lang bepaalde vormen en organen zou zijn. Die praeformatie kon liggen in de door het mannelijk ouderorganisme afgestane stof; onder de "animalculisten" die dit meenden, namen onze landgenooten LeEUWFNHOEK en BoERHAAve een belangrijke plaats in, terwijl tot de ,ovisten”, die geloofden het gepraeformeerde te moeten zien in het $\mathrm{ei}$, dus in het aandeel der 
moeder, Swammerdam en andere bekende natuuronderzoekers gerekend mogen worden. Tot in uiterste consequenties doorgedreven, leidde de praeformatisten-opvatting natuurlijk tot dwaasheden; de afbeeldingen in oude werken van spermacellen, waarin een geheel menschelijk organisme van mikroskopische afmetingen te zien is, of de berekening van MALEBRANCHE, hoeveel menschelijke eicellen in het ovarium van Eva moeten aanwezig geweest zijn, behoorden natuurlijk tot de bedenkelijke gevolgen, waartoe een vurige verdediging van een sterk bestreden standpunt leiden kan.

De reactie tegen de al te ver doorgevoerde praeformatistenopvatting werd het eerst geleid door BuFfon en kwam tot haar hoogtepunt door het werk van C. F. WolfF, die in zijn Theoria generationis getracht heeft, de theorie der praeformatie te vervangen door een theorie der epigenesis. In de voortplantingscellen is volgens WOLFF nog niets gepraeformeerd; alles is op het moment der bevruchting nog volkomen zonder eenige structuur, eerst langzamerhand wordt het anorganische organisch, georganiseerd, doordat blaasjes en vaten ontstaan. De oorzaak van die omzetting van anorganische stof in organische is een zonder verdere omschrijving aangenomen "vis essentialis".

Grooter contrast dan tusschen deze oorspronkelijke praeformatistische en epigenetische richtingen in de voortplantingsleer is wel niet denkbaar, en het behoeft geen nader betoog, dat in hun uitersten vorm beide onjuist zijn en dat de moderne bevruchtingsphysiologie daartusschen in staat, waarbij zooals vanzelf spreekt, de eene onderzoeker meer naar de eene, de andere meer naar de tegenovergestelde zijde gewend is.

Dergelijke antipoden van opvatting treffen we nu ook in de erfelijkheidsleer aan: in primitiefste opvatting vinden we reeds bij Aristoteles en bij Hippokrates uitingen, die de meest uiteenloopende standpunten vertegenwoordigen. Het is de groote verdienste van JoHANNSEN geweest, erop te hebben gewezen, hoe twee principieel verschillende theorieën, die thans nog beide verdedigers en beide bestrijders vinden, reeds in de Grieksche litteratuur in primitieveren vorm teruggevonden kunnen worden (zie JohanNSEN 1907 a en b). Hippokrates meende de erfelijkheid van lichaamseigenschappen te kunnen verklaren door aan te nemen; dat ieder lichaamsdeel, ook het kleinste, een kiempje afgeeft en 
dat al deze kiempjes zich zouden verzamelen in één centraal lichaam, n.l. datgene wat door de ouders bij de bevruchting afgestaan wordt; ARISTOTELES dacht zich de gang van zaken juist andersom: uit een centrale massa ,zaad”, waarin alle lichaamsdeelen in aanleg aanwezig zijn, wordt in de eerste plaats het opgroeiende lichaam gevormd, dat door het opnemen en omzetten van voedsel van buitenaf grooter worden kan; voor den bouw van de deelen van dit lichaam is niet al het voorhanden "zaad" noodig, zoodat er een restant overblijft en dit restant is op zijn beurt oorsprong van de volgende generatie. Zooals een schilder van alle verven op zijn palet iets gebruikt, om het schilderij te maken, maar ook van alles iets overlaat voor een volgend schilderij, zoo meent ARISTOTELES de oorzaak van gelijkheid tusschen ouders en kinderen te kunnen verklaren, doordat beide uit dezelfde stof gevormd zijn en deze stof van generatie tot generatie onveranderd verder gaat.

Het principieele verschil tusschen beide opvattingen wordt duidelijk voor oogen gebracht door een aan JoHANNSEN ontleende afbeelding (fig. 1). Ieder levend organisme, dat sexueele voortplanting bexit, ontstaat uit een enkele eicel, waarin een spermatozoïde binnendringt; beide cellen smelten geheel samen en uit deze bevruchte eicel wordt het geheele lichaam van dier of plant opgebouwd. Dat is voorgesteld in fig. 1. I, waar de bevruchte eicel oorsprong geeft aan het lichaam der visch. Gaat nu deze visch haar voortplantingscellen (eicellen of spermacellen) maken, dan moeten we aannemen, dat de erfelijke eigenschappen, die van vader en moeder op het kind overgaan, op het oogenblik der bevruchting in een of anderen vorm in die voortplantingscellen aanwezig zijn en er dus op een of andere wijze in gebracht worden òf van het begin af aan daarin voorhanden waren. De eerste opvatting zouden we epigenetisch kunnen noemen, al is ze niet volkomen vergelijkbaar met de epigenetische richting der bevruchtingsphysiologie; het is de Hippokratische, afgebeeld in fig. 1. II; alle deelen van het lichaam geven kiempjes af, die zich in de bloedbaan verzamelen en door het bloed naar de voortplantingsorganen gevoerd worden: Daartegenover het andere standpunt: van het begin af zijn alle erfelijke eigenschappen in de voortplantingscellen anwezig; de voortplantingscellen van alle opeenvolgerde generaties vormen een 
onafgebroken reeks en bet lichaam ontstaat telkens opnieuw uit

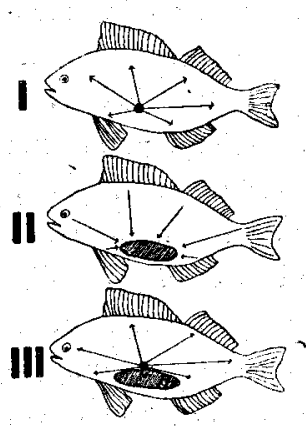
een deel van dit erfelijk materiaal; al zijn eigenschappen zijn daarin gepraeformeerd. Die voorstelling is Aristotelisch of praeformatistisch.

Eeuwen lang blijft dan het vraagstuk der erfelijkheid op den achtergrond; andere problemen nemen haar plaats in, totdat in de medische litteratuur van de eerste helft der negentiende eeuw de belangstelling voor erfelijkheidsverschijnselen begint wakker te worden: J. F. MECKEL gaf in zijn handboek der menFig. 1 (naar Johannsen). schelijke anatomie (1812) een opsomming van menschelijke lichaamsafwijkingen, die in verschillende generaties achtereenvolgens optraden; HOFACKER stelde in 1828 tal van hem bekende erfelijke eigenschappen bij mensch en dier samen, in het bijzonder met het oog op de paardenfokkerij; ProsPER LuCAS publiceerde in 1847 een uitvoerige beschouwing over den physiologischen en psychologischen kant van het erfelijkheidsvraagstuk, vooral voorzoover dit zenuwaandoeningen betreft. Door hen werd rijkelijk materiaal : verzameld, maar een verheldering van inzichten in het erfelijkheidsproces werd daarmee niet verkregen, een theorie op die feiten gebaseerd, bleef uit.

Totdat ook in dit opzicht de kentering in belangstelling voor de biologische naturwetenschappen haar invloed deed gelden en als eerste onder een rij van schrijvers Herbert Spencer in zijn Principles of Biology (1864) zijn meening te kennen gaf over de natuur der erfelijkheid. Baseerend op waarnemingen, vooral uit de medische litteratuur verzameld, trachtte SpENCER als onderdeel van zijn systeem eener synthetische philosophie ook alle groepen van verschijnselen der biologie op te nemen; als één dier groepen geldt dan de erfelijkheid, waarvan hij de oorzaak in de volgende richting zoekt: In ieder organisme wordt het geheel der erfelijke eigenschappen bepaald door een bepaalde eenheid; de vraag is nu, van wat voor aard die eenheden zijn. Chemische eenheden (chemical units) zijn daartoe niet voldoende; de groote veelvormigheid van organismen is met behulp daarvan niet te verklaren; „morphological units" (cellen) kunnen we ook niet als zoodanig in aanmerking nemen, omdat een meercellig organisme zijn specifieke structuur 
onfleent aan de samenwerking van de cellen, die aan zijn opbouw deelnemen en dus een enkele cel, die niet samenwerkt met andere, geen specifieke structuur veroorzaakt.

Als eenige aannemelijke eenheid, waarin de erfelijke eigenschappen van een organisme hun grond kunnen vinden, acht SPEncer de physiologische eenheid (physiological unit) van beteekenis, die zóó gekarakteriseerd wordt: „There seems no alternative büt to suppose that the chemical units combine into units immensely more complex than themselves, complex as they are, and that in each organism the physiological units produced by this further compounding of highly compound molecules, have a more or less distinctive character. We must conclude that in each case some difference of composition in the units, or of arrangement in their components, leading to some difference in their mutual play of forces, produces a difference in the form which the aggregate of them assumes." (1898. p. 226). Zoo is dus ieder organisme gekenmerkt door een complex van scheikundige stoffen, die alle met elkaar een physiologische eenheid vormen. Die physiologische eenheid is dan verantwoordelijk voor de erfelijke eigenschappen van het organisme. Ze wordt van het ouder-organisme op de kinderen overgebracht door de voortplantingscellen, die uitsluitend den rol van vervoermiddel spelen: "And here the assumption to which we seem driven by the ensemble of evidence, is, that the sperm-cells and germ-cells are essentially nothing more than vehicles in which are contained small groups of the physiological units in a fit state for obeying their proclivity towards the structural arrangement of the species they belong to." (1898, p. 317).

Is nu die physiologische eenheid volgens SPENCER een onveranderlijk, van te voren gegeven, geheel, of werken de veranderingen, die het uitwendige van het organisme ondergaat tengevolge der levensomstandigheden, terug op de physiologische eenheid? M. a.w. is de theorie der physiological units streng praeformatistisch of laat ze ruimte voor $\min$ of meer epigenetisch getinte beschouwingen?

Zonder eenigen twijfel is SpEncers opvatting van vrij sterk epigenetisch karakter en is in zijn meening de physiologische eenheid veranderlijk onder invloed der levensomstandigheden. Getuige zijn volgende woorden: „Or, bringing the question to its ultimate and simplest form, we may say that as, on the one hand, physiological 
units will, because of their special polarities, build themselves into an organism of a special structure; so, on the other hand, if the structure of this organism, is modified by modified function, it will impress some corresponding modification on the structures and polarities of its units. The units and the aggregate must act and re-act on each other. If nothing prevents, the units will mould the aggregate into a form of equilibrium with their pre-existing polarities. If, contrariwise, the aggregate is made by incident actions to take a new form, its forces must tend to re-mould the units into harmony with this new form." (1898. p. 319).

Gegeven is dus volgens SPENCER vooraf een stel physiologische eenheden, die onder gewone omstandigheden het lichaam opbouwen naar het vooraf bepaalde ontwerp; onder buitengew one omstandigheden neemt het lichaam een anderen vorm aan, dan oorspronkelijk bepaald was, deze vorm wordt nu terugwerkend in de physiologische eenheden vastgelegd en op de nakomelingen overgebracht. Gedeeltelijk dus gepraeformeerd, kan toch de erfelijke aanleg van een organisme later veranderen.

$\mathrm{Nu}$ volgt eenige jaren later (1868) DARwIN, die in zijn ,Variation of animals and plants" een meer uitgewerkte erfelijkheidstheorie opstelde, gefundeerd op waarnemingen in de natur en in de cultuur, zorgvuldig naar hun waarde beoordeeld en zooveel hem toentertijd mogelijk was, kritisch beschouwd. Uit alle door hem verzamelde feiten kwam DARWIN tot het opstellen van een vijftal „wetten der erfelijkheid", waarover hij reeds in 1859 in zijn "Origin of species" vaag gesproken had (1860. p. 12), maar die hij thans voor het eerst bepaald samenvattend als volgt formuleerde: „Firstly, a tendency in every character, new and old, to be transmitted by seminal and bud generation, though often counteracted by various known and unknown causes. Secondly, reversion or atavism, which depends on transmission and development being distinct powers; it acts in various degrees and manners through both seminal and bud generation. Thirdly, prepotency of transmission, which may be confined to one sex, or be common to both sexes. Fourthly, transmission, as limited by sex, generally to the same sex in which the inherited character first appeared; and this in many, probably most cases, depends on the new character having first appeared at a rather late period of life. Fifthly, inheritance at corresponding periods of 
life, with some tendency to the earlier development of the inherited character." (1888. II. p. 61).

Dat waren voor DARWIN vaststaande regels, waaraan de erfelijk. heid onderworpen was, en voor die regels trachtte hij een verklaring te vinden door zijn bekende hypothese der pangenesis, die hij in hetzelfde werk aan zijn mede-onderzoekers ter discussie bood, daarbij uitdrukkelijk zijn hypothese als een voorloopige kenschetsend. Hij erkent dan ook, dat zijn hypothese uit een aantal veronderstellingen bestaat. "It is universally admitted that the cells or units of the body increase by self-division or proliferation, retaining the same nature, and that they ultimately become converted into the various tissues and substances of the body. But besides this means of increase $I$ assume that the units throw off minute granules which are dispersed throughout the whole system; that these, when supplied with proper nutriment, multiply by self-division, and are ultimately developed into units like those from which they were originally derived. These granules may be called gemmules. They are collected from all parts of the system to constitute the sexual elements, and their development in the next generation forms a new being; but they are likewise capable of transmission in a dormant state to future generations and may then be developed. Their development depends on their union with other partially developed or nascent cells which precede them in the regular course of their growth. Gemmules are supposed to be thrown off by every unit, not only during the adult state, but during each state of development of every organism; but not necessarily during the continued existence of the same unit. Lastly, I assume that the gemmules in their dormant state have a mutual affinity for each other, leading to their aggregation into buds or into the sexual elements. Hence, it is not the reproductive organs or buds which generate new organisms, but the units of which each individual is composed. These assumptions constitute the provisional hypothesis which I have called Pangenesis" (1888 p. 369-370).

Die pangenesis-hypothese is dus wel een heel gebouw van veronderstellingen, en het is dan ook zeker wel aan de oncontroleerbaarheid der in DARwins tijd bekende feiten toe te schrijven, dat DARwIN in zijn gevolgtrekkingen niet gelukkiger is geweest. In twee opzichten verschilt ze van de opvattingen van SPENCER: 
physiologische eenheden werden verondersteld alle van dezelfde soort te zijn, terwijl DARWIN zijn kiempjes of gemmulae van zeer verschillende soorten, al naar het orgaan dat ze heeft afgegeven, beschouwt (vgl. Spencer 1898. p. 356). En bovendien is van het vervoer dier eenheden van de lichaamscellen naar de voortplantingscellen bij Spencer geen sprake. Dit laatste is dan ook wel het zwakste punt in DARWINS hypothesen-complex; een veronderstelling, die bij zijn opvolgers al beel weinig instemming gevonden heeft, en die door velen van hen volkomen verlaten werd. Bij DARWIN is in de voortplantingscel eigenlijk niets gepraeformeerd; alles komt van buitenaf en wordt slechts in die voortplantingscel opgeborgen om naar latere generaties over te gaan. Van alle praemendelistische erfelijkheidsbeschouwingen staat die van DARWIN het meest aan epigenetischen kant; door de veronderstelling der transportmogelijkheid van gemmulae laat ze ruimte aan alle mogelijke fantasie.

Toch is de pangenesis-hypothese van DARwin historisch van grooter beteekenis geweest, dan de theorie van SPencer, èn omdat ze de eerste consequente uitwerking vormde van de reeds bij Hippokrates in vager vorm te vinden veronderstellingen (vg). MAY 1917) èn vooral omdat ze meer de algemeene aandacht getrokken heeft en daardoor uitgangspunt geworden is voor andere onderzoekers, die allen min of meer belangrijke wijzigingen in DARwINs uiteenzettingen hebben aangebracht.

In verschillende richtingen waren zulke veranderingen te vinden: in positieve en in negatieve richting. D. w. z. lang niet iedere theorie der erfelijkheid, die in plaats van DaRwiNs pangenesis gesteld werd, was een verbetering; er zijn er, zooals wel de plastidulen-hypothese van HAECKEL (1876), die beter als produkten van een dichterlijk-fantastischen geest beschouwd kunnen worden, dan als ernstig-wetenschappelijke, op feiten gebaseerde hypothese. Terecht kenmerkt NaEgeli (1884. p. 81) de theorie van HaEckel als „ein Product der Naturphilosophie und als solches so gut wie jedes andere aus der gleichen Quelle erflossene Product. Ihr Fehler wie bei jeder naturphilosophischen Lehre ist der, dass sie ihre Ahnungen als Thatsachen ausgibt and für dieselben unpassende naturwissenschaftliche Bezeichnungen braucht und in unberechtigter Weise naturwissenschaftliche Bedeutung in Anspruch nimmt". 
Ditzelfde verwijt zouden we tegen een groot aantal jongere erfelijkheids-theorieën kunnen aanvoeren, die alle gepoogd hebben een voorstelling te vormen van de moleculaire werkingen, die in het materieele, aan erfelijkheid ten grondslag liggende, substraat plaats vinden. Die theorieën, talrijk als het zand der zee, zullen we hier dan ook terzijde laten; daarover kan men bij DelaGe (1895) voldoende uiteenzettingen vinden. Dat daaronder ook de Micellair-hypotbese van N.̈GELI zelf (1884) behoort gerekend te worden, is aan NäGELl's eigen al te philosophische natur te wijten. Iedere gedetailleerde uitwerking eener hypothese aangaande de natuur der pangenen, van den stoffelijken grondslag der erfelijke eigenschappen is nog tegenwoordig hypothese, al begint er sedert eenige jaren een experimenteel-gevonden basis te komen, waarop voortgebouwd kan worden; hoeveel te meer had dit betrekking op den tijd vóór 1900, toen over dat probleem nog niet eens hypothesen, slechts fantastische beschouwingen gegeven konden worden.

Werkelijke verbetering van DARwins pangenesis-hypothese was echter alleen te krijgen, door haar te ontleden in haar verschillende onderdeelen en dan ieder dier onderdeelen als op zichzelf staand probleem te onderzoeken. Onmiddellijk valt dan een punt op, dat ook reeds spoedig na de publicatie den aandacht getrokken heeft en dat de zwakste plek in de pangenesis-constructie was: de transporteerbaarheid der pangenen.

Daartegen trok de meerderheid der onderzoekers te velde; daarin werd dan ook terecht het zwaartepunt gezocht van de pangenesis-hypothese. Niet iedere aanval was even krachtig; in de jaren na 1870 werd de voornaamste bestrijding gevoerd door BRooks (1883), de VRies (1889), Galton (1876, 1889) en WeisMANN (1883 e. a.). Die genoemde volgorde drukt vrijwel de verschillen in standpunt uit, die tusschen Darwin en de genoemde onderzoekers lagen, Brooks' tegenstand het zwakste, die van WEISMaNn het sterkste.

Allereerst de beschouwingen van Brooks. Hij zelf karakteriseert de hoofpunten van zijn ,new theory of heredity" met de volgende woorden $(1883$, p. $81-82)$ :

"The anion of two sexual elements gives variability. Conjugation is the primitive form of sexual reproduction. Here the fun- 
ctions of the two elements are alike, and the union of parts derived from the bodies of two parents simply insures variability in the offspring.

„In all multicellular organisms the ovum and the male cell have gradually become specialized in different directions.

"The ovum is a cell which has gradually acquired a complicated organization, and which contains material particles of some kind to correspond to each of the hereditary characteristics of the species.

"The ovum, like other cells, is able to reproduce its like, and it not only gives rise during its development to the divergent cells of the organism, but also to cells like itself.

„The ovarian ova of the offspring are these latter cells, or their direct unmodified descendants.

„Each cell of the body is, in a morphological sense, an independent individual. It has the power to grow, to give rise by division to similar cells, and to throw off minute germs. During the evolution of the species it has by natural selection acquired distinctive properties or functions, which are adapted to the conditions under which it is placed. So long as these conditions remain unchanged it performs its proper function as a part of the body; but when, through a change in its environment, its function is disturbed and its conditions of life become unfavorable, it throws off small particles which are the germs or ,gemmules" of this particular cell.

„These germs may be carried to all parts of the body. They may penetrate to an ovarian ovum or to a bud, but the male cell has gradually acquired, as its especial and distinctive function, a peculiar power to gather and store up germs.

"When the ovum is fertilized each germ or "gemmule" unites with, conjugates with, or impregnates, that particle of the ovum which is destined to give rise in the offspring to the cell which corresponds to the one which produced the germ or gemmule; or else it unites with a closely related particle, destined to give rise to a closely related cell.

"When this cell becomes developed in the body of the offspring it will be a hybrid, and it will therefore tend to vary.

"As the ovarian ova of the offspring share by direçt inheritance 
all the properties of the fertilized ovum, the organisms to which they ultimately give rise will tend to vary in the same way.

„A cell which has thus varied will continue to throw off gemmules, and thus to transmit variability to the corresponding part in the bodies of successive generations of descendants until a favorable variation is seized upon by natural selection".

Drie punten zijn terstond aan te wijzen, ten opzichte waarvan Brooks' uiteenzetting anders is dan die van DARwIN. In de eerste plaats is de vervoerbaarheid der stoffelijke kiempjes zeer beperkt ; bij Darwin gaf iedere normale cel een kiempje af, bij Brooks doen de cellen dit alleen wanneer ze onder abnormale verhoudingen zich ontwikkelen; dus is eigenlijk volgens deze opvatting het transport van kiempjes een oorzaak van variabiliteit, niet van erfelijkheid. In de tweede plaats zijn het in het bijzonder de mannelijke voortplantingscellen, die de afgestooten kiempjes op. vangen en verzamelen, een merkwaardige en ons tegenwoordig vrijwel waardeloos schijnende verandering in de pangenesis-hypothese. En ten derde wil Brooks, al drukt hij zich te dien opzichte niet in overduidelijke bewoordingen uit, de toekomstige eicellen direct afleiden van de bevruchte eicel, immers $z i j$,share by direct inheritance all the properties of the fertilized ovum". Van die punten zijn het eerste en het derde ongetwijfeld de belangrijkste; ze wijzen beslist in een meer praeformatistische richting, die Brooks wilde ingaan, maar hij deed dit eigenlijk alleen uit reactie tegen de tever doorgevoerde epigenetische uiteenzeltingen Ian DARWIN.

Meer nog aan de zijde der praeformatisten schaart zich DE VRIES, die in 1889 in plaats van DARwins intercellulaire een intracellulaire pangenesis plaatst. M. a. w. DARWIN nam het vervoer van gemmulae aan van de lichaamscellen door het lichaam been naar de voortplantingscellen; DE VRIES ontkent dit ten sterkste, meent dat de pangenen uitsluitend vanuî́ de celkern naar het protoplasma kunnen gaan en in dit laatste zich kunnen blijven rondbewegen. Er bestaat dus geen gelegenheid om veranderingen in de lichaamscellen, ontstaan tengevolge van veranderde uitwendige omstandigheden, op de nakomelingen over te brengen. DE VRIEs' intracellulaire pangenesis is meer een hypothese ter verklaring van de differentiatie der lichaamscellen, dan van de erfelijkheid; temeer 
waar DE VRIES zich ten opzichte der erfelijkheid vrijwel geheel aan de zijde van WeISMANn plaatst.

Principieeler erfelijkheidstheorie dan de intracellulaire pangenesis, was reeds jaren tevoren, ongeveer tegelijk met DARwIN, gegeven door Galton, en hij was dan ook eigenlijk de eerste belangrijke tegenstander der darwinistische pangenesishypothese. Galton zag onmiddellijk de groote moeilijkheden, die de transporthypothese opleverde. Hij begon met enkele proefnemingen in elkaar te zetten, die de al of niet houdbaarheid dezer veronderstelling moesten kunnen aantoonen. In zijn autobiographie vertelt hij daarover: „According to DARWIN's theory, every element of the body throws off gemmules, each of which can reproduce itself, and a combination of these gemmules forms a sexual element. If so, I argued, the blood which conveys these gemmules to the places where they are developed, whether to repair an injured part or to the sexual organs, must be full of them. They would presumably live in the blood for a considerable time. Therefore if the blood of an animal of one species were largely replaced by that of another, some effect ought to be produced on its subsequent offspring. For example, the dash of bull-dog tenacity that is now given to a breed of greyhounds by a single cross with a bull-dog, the first generation corresponding to a mulatto, the second to a quadroon, the third to an octoroon, and so on, might be given at once by transfusion. Bleeding is the simplest of operations, and I knew that transfusion had been performed on a large scale; therefore I set about making minute inquiries".

"These took a long time, and required much consideration. At length I determined upon trying the experiment on the well-known breed of rabbits called silver greys, of which pure breeds were obtainable, and to exchange much of their blood for that of the common lop-eared rabbit; afterwards to breed from pairs of silver greys in each of which alien blood had been largely transfused. This was done in 1871 on a considerable scale. I soon succeeded in establishing a vigorous cross-circulation that lasted several minutes between rabbits of different breeds, as described in the Proceedings of the Royal Society, 1871. The experiment were thorough, and misfortunes very rare. It was astonishing to see how quickly the rabbits recovered after the effect of the anaesthetic had 
passed away. It often happened that their spirits and sexpal aptitudes were in no way dashed by an operation; which only a few minutes before had changed nearly one half of the blood that was in their bodies. Out of stock of three silver grey bucks and four silver grey does, whose blood had been thus largely adulterated, and of three common bucks and four common does whose blood had been similarly altered, I bred eighty-eight rabbits in thirteen litters without any evidence of alteration in breed. All this is described in detail in the Memoir". (1908 p. 296-7.)

Belang heeft dit citaat niet zoozeer om den uitslag der proeven, als wel omdat het bewijst, dat Galton toentertijd een juist inzicht had in den weg, die alleen leiden kan tot een gegronde beoordeeling eener hypothese. Die weg was het experiment.

Dat Galtons proefnemingen voor de transporthypothese geen steun konden vinden, verwondert ons tegenwoordig geenszins; dat ze ondanks de vrij $z$ wakke plekken, waarvan zijn experimenten niet vrij waren, voor hem van doorslaande beteekenis geweest zijn, heeft zijn goede zijde gehad, omdat GALTON daardoor geko. men is tot eigen opvattingen, die van de darwinistische hemels. breed verschilden.

Galton was op het gebied dèr erfelijkheid reeds een vooraanstaand man, toen DARwiNs pangenesis verscheen; hij had weliswaar toen nog niet meer dan een klein artikeltje over erfelijkheid van talent en karakter gepubliceerd, maar was reeds lang bezig met een uitgebreide studie van hetzelfde materiaal, kort na DARwiNs Variation verschenen als „Hereditary genius” (1869). Daarin verklaart GaLton, onder den eersten indruk dien de genialiteit van de pangenesishypothese op hem gemaakt heeft, dat "the theory of Pangenesis brings all the influences that bear on heredity into a form, that is appropriate for the grasp of mathematical analysis" (1869. p. 358). Meer zegt hij er niet over; hij wil wel de juistheid veronderstellen, maar gelooft toch, dat die nog bewezen zal moeten worden.

Zeven jaar later heeft hij zijn standpunt ten opzichte der pangenesis-hypothese kunnen vaststellen; in een artikel van klassieke waarde "A Theory of Heredity" (1876) steunt hij op zijn proefnemingen, waarvan de uitkomsten negatief waren, en stelt hij in plaats van de pangenesis een andere erfelijkheidstheorie voor. 
Alle gevallen, waarvoor een erfelijkheidstheorie een verklaring moet geven, kunnen geschikt in twee groepen verdeeld worden: de eene omvat alle aangeboren eigenaardigheden, die ook in een of meer der voorouders als aangeboren voorkwamen, de andere die eigenschappen, die niet als aangeboren bij de voorouders gevonden werden, maar voor het eerst tijdens hun leven tengevolge van veranderde levensomstandigheden werden verkregen. Van deze beide groepen is de eerste de meest belangrijke om het groote aantal vaststaande feiten dat daartoe behoort; de tweede omvat veel gegevens van twijfelachtige waarde. De verschijnselen van de eerste groep moeten voor de andere verklaard worden; een erfelijkheids-theorie heeft vooral daarmee rekening te houden. GaLton wil gaarne aannemen, dat aan alle erfelijke eigenschappen bepaalde "organic units" ten grondslag liggen, maar hij komt terug van de opvatting, dat er tusschen deze eenheden geen verband zou bestaan. Ze vormen met hun alle een geheel, een totaal, dat hij stirp noemt. "Before proceeding, I beg permission to use, in a special sense, the short word "stirp" derived from the Latin stirpes, a root, to express the sum-total of the germs, gemmules, or whatever they may be called, which are to be found, according to every theory of organic units, in the newly fertiliszed ovum" (1876 p. 330).

Met het invoeren van deze uitdrukking doet Galton een zeer belangrijke stap terug van de door DARWIN aangenomen geheel onafhankelijke gemmulae; alle gemmulae behooren bij elkaar en vormen samen een geheel. Toch neemt ook GALTON wel bet bestaan van deze eenheden in zijn beschouwingen op: „Four postulates seem to be almost necessarily implied by any hypothesis of organic units and are included in that of pangenesis. The first is, that each of the enormous number of quasi-independent units of which the body consists, has a separate origin, or germ. The second is, that the stirp contains a host of germs, much greater in number and variety than the organic units of the bodily structure that is about to be derived from them; so that comparatively few individuals out of the host of germs, achieve development. Thirdly that the undeveloped germs retain their vitality: that they propagate them. selves while still in a latent state, and contribute to form the stirps of the offspring. Fourthly that organization wholly depends 
on the mutual affinities and repulsions of the separate germs; first in their earliest stirpal stage, and subsequently during all the processes of their development." (1876. p. 331).

Geheel nieuw en bij geen zijner voorgangers zoo belder uitgesproken is hierin de derde stelling: dat de kiempjes zichzelf vermenigvuldigen, terwijl $z e$ in een latenten toestand verkeeren, en bijdragen om de "stirp" van de nakomelingen te vormen. Scherper zegt hij nog hetzelfde in deze woorden: "We have thusfar dealt with three agents: (1) the stirp, which is an organised aggregate of a host of germs; (2) the personal structure, developed out of a small portion of those germs; and (3) the sexual elements, generated by the residuum of the stirp." (1876. p. 343). Er is dus geen sprake meer van een verzamelen van gemmulae in de voortplantingscellen, maar van een doorloopende keten, die de voortplantingscellen van een individu vormen met die van zijn nakomelingen. In GaLtoN's hoofdwerk over erfelijkheid in het algemeen: "Natural inheritance", drukt hij zijn opvatting zóó uit: „It appears that there is no direct hereditary relation between the personal parents and the personal child, but that the main line of hereditary connection unites the sets of elements out of which the personal parents had been evolved with the set out of which the personal child was evolved. The main line may be rudely likened to the chain of a necklace, and the personalities to pendants attached to its links." (1889. p. 19). Het essentieele verschil tusschen deze beide opvattingen : het pangenentransport van DARwIN en de stirpopvatting van GALTON kunnen we weer door een figuur verduidelijken. Men vindt dit schema in figuur 2. Uit de kiemcellen of voortplantingscellen ( $\mathrm{KC}$ ) wordt het lichaam van het organisme (L) gevormd; volgens DARWIN geeft dit weer aanleiding tot nieuwgevormde kiemcellen, terwijl volgens GaLton de kiemcellen, waaruit de individuën der volgende generatie

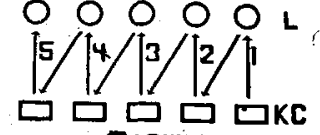
DARWIN

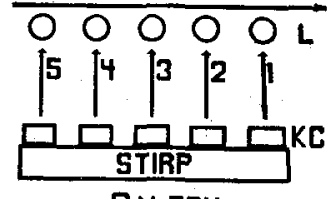

GALTON

Figuur 2. ontstaan, direct aan het resida van erfelijke substantie, de stirp, hun oorsprong danken.

Toch wist ook Galton ondanks zijn uitgesproken praeformatistische standpunt zich niet geheel en al aan epigenetische invloeden 
te onttrekken. Er waren in zijn tijd nog steeds argumenten te over aan te voeren voor een, ,erfelijkheid van verworven eigenschappen", die dus neerkomt op een verandering van de stirp, van dén erfelijken aanleg van het organisme, doorde uitwendige omstandigheden, dus via de lichaamscellen òf direkt. Die veranderingen in de ,stirp”, die hij meende te moeten aannemen, waren wel, vergeleken met de erfelijkheid zelf, van ondergeschikte beteekenis, maar ze waren toch voldoende aanleiding voor hem om een achterdeur open te houden. Er waren individueele verschillen tusschen organismen, die van dezelfde "stirp" af komstig waren, en die ,individueele variabiliteit" kon twee oorzaken hebben. "Individual variability depends upon two factors; the one is the variability of the germ and of its progeny; the other is that of all kinds of external circumstances, in determining which out of many competing germs of nearly equal suitability, shall be the one that becomes developed. The variability of germs under changed conditions, and that of their progeny may be small, but it is undubitable; absolute uniformity being scarceley conceivable in the condition and growth, and therefore in the reproduction of any organism. The law of heredity goes no farther than to say, that like tends to produce like; the tendency may be very strong, but it cannot be absolute. The effect of the second of the factors mentioned above, is that a very slight variation in the germs may have a momentous effect in the personal structure that is developed out of a comparatively small number of them. There are numerous competing germs in the place of each unit of structure, and only one of the competitors can succeed in any case". (1876. p. 338). En bovendien acht hij het nog noodig, al is het in zeer geringe mate, kiempjes-transport aan te nemen. "Each cell may be supposed to throw off a few germs that find their way into the circulation and thereby to acquire a chance of occasionally finding their way to the sexual elements and of becoming naturalised among them". (1876. p. 346).

Een ander punt, dat Galton in verband met zijn stirp-theorie onder oogen moest zien, was dat van de verhouding der beide ouders met betrekking tot hun nakomelingen. Stamde een organisme slechts van een enkel ander af, dan liet de stirp zich als onverbreekbare keten tusschen alle voortplantingscellen der opvoigende generaties gemakkelijk aannemen; werd echter een individu uit 
twee ouders geboren, dan makkte dit een andere uiteenzetting noódig. Daarop gaat GALTON uitvoerig in in een verhandeling over ,The average contribution of each several ancestor to the total heritage of the offspring" (1897). Hierin en in een kort artikel in Nature fundeert hij een nieuwe erfelijkheidswet; "It is that the two parents contribute between them on the average one half or (0.5) of the total heritage of the offspring; the four grandparents, one-quarter or $(0,5)^{2}$; the eight great-grandparents, one-eighth, or $(0.5)^{3}$; and so on. Thus the sum of the ancestral contributions is expressed by the series $\left\{(0.5)+(0.5)^{2}+(0.5)^{3}\right.$, etc $\}$ which, being equal to 1 , accounts for the whole heritage." (1897. p. 402).

Schematisch stelde Galton het volgende jaar (1898) zijn opvatting omtrent het aandeel, dat de voorouders aan de erfelijke structuur der nakomelingen hebben zouden, voor door de in figuur 3 weergegeven afbeelding. Ais 2 en 3 zijn hierin de ouders, als $4,5,6$ en 7 de grootouders, als $8,9,10,11,12,13,14$ en 15 de overgrootouders enz. aangegeven, terwijl het geheele vierkant den erfelijken aanleg van het individu bevat (figuur 3 ).

Dat was de stirp-leer in haar uiterste consequentie doorgevoerd; en indien dit juist was, dan zouden de verschillen tusschen individuën, welke van eenzelfde paar ouders afstammen, uitsluitend het gevolg moeten zijn van levensomstandigheden. Zulke individuën vormen een "fraternity" en over de verschillen in fraternities zegt hij dan ook: "Gircumstance comprises all the additional accidents and all the peculiarities of nurture both before

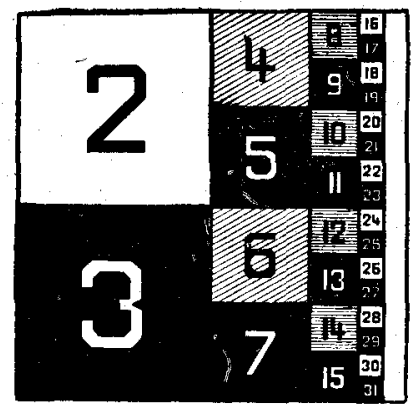

Figuur 3 (naar Galton). and after birth, and every influence that may conduce to make the characteristics of one brother differ from those of another" (1889. p. 195).

Het is jammer, dat Galton, die hier en daar in zijn werk toonde veel waarde te hechten aan experimenten ten bewijze van een bepaalde opvatting, ten opzichte van dit laatste punt niet meer waarde heeft weten te hechten aan de experimenten van MENDEL. Hij heeft Mendels werk gekend en is zelfs tot het inzicht gekomen, 
dat "MENDEL clearly showed that there were such things as alternative atomic characters of equal potency in descent" (1908, p. 308). Maar hij heeft niet begrepen, dat de eenvoudige resultaten van MENDELs werk zijn "law of ancestral inheritance". overboord wierpen, en dat het eenvoudige door MENDEL aangetoonde feit: de door een organisme gevormde voortplantingscellen kunnen onderling van zeer verschillenden erfelijken aanleg zijn, met die wet in flagranten strijd was. Dat is jammer, omdat de stirpleer een goede vooruitgang was in praeformatistische richting, en die vooruitgang thans overschaduwd werd door een tever doorgevoerde, en daardoor onjuiste consequentie.

Zóóver moest men dus praeformatistische beschouwingen niet doorvoeren; langs dezen laatsten door GALTon aangegeven weg, loopen ze op een dood spoor. Dit is jujst gezien door den laatste der op den voorgrond tredende praemendelistische erfelijkheidstheoretici, Augusi Weismann, die in de rij tevens de meest volhardende praeformatist geweest is. WeIsmanN's positie ten aanzien van het erfelijkheids-vraagstuk was een geheel andere dan die van Galton; Weismann stond middenin de levendige en opgewekte spheer van onderzoekingen en beschouwingen, die in de tweede helft van de negentiende eeuw de Duitsche natuurwetenschap kenmerkte; hij nam zelf een groot deel daarvan voor zijn rekening, werkte en publiceerde over veel zoölogische onderwerpen en was onder de vooraanstaande mannen in Duitschland een der meest geziene. Terwijl GaLton sterk op zichzelf aangewezen was, vrijwel alleen stond en niet beschikte over een breede kennis van biologische gegevens, had WEISMANN ruimer materiaal tot zijn beschikking, stond hij in nauw contact met de groote geesten op het gebied van bevruchtings- en voortplantingsleer, was hij tijden landgenoot en gelijke van O. Hertwig en Strasburger. Zoo kon WEISMANN zijn opvattingen steviger fundament geven, dan Galton, die meer de man van de geniale intuïtie was.

Reeds hadden Bütschli (1876), JäGER (1878) en Nussbaum (1880) opvattingen verkondigd, analoog aan de stirp-theorie van GalToN, toen WeIsMaNN, na eenige voorafgaande min of meer vage beschouwingen in 1885 voor den dag kwam met zijn rede over de continuïteit van het kiemplasma op de Naturforscherversammlung in Straatsburg en spoedig daarop ditzelfde onderwerp in een uit- 
voerige verhandeling aan de natuurwetenschap voorlegde (1885). J ̈̈GER had in zijn werk de meening geopperd, dat het lichaam van hoogere organismen uit tweeërlei cellen zou bestaan; uit ontogenetische en uit phylogenetische, waarvan de laatsten, de voortplantingscellen niet als produkt van de eersten, de lichaamscellen gevormd worden, maar direkt van de voortplantingscellen der ouders afstammen. Hij beschouwde het vrijwel als bewezen, "dat de vorming der voortplantingsstoffen reeds in de eerste stadiën van het embryonale leven plaats vindt". En dit is later ook de grondslag geweest, waarop WeISMaNN zijn theorie over de continuiteit van het kiemplasma bouwde. Ook hij meende, en in enkele gevallen toonde hij dit ook door eigen onderzoek aan, dat reeds vroeg tijdens het embryonale leven, bepaalde deelen afgezonderd worden, die dan later den oorsprong zouden vormen van de toekomstige voortplantingscellen; deze deelen werden eigenlijk uit de verdere ontwikkeling van bevruchte eicel tot volwassen lichaam uitgeschakeld en zoolang bewaard, tot het tijdstip van rijpheid van dit lichaam gekomen zou zijn en dit zelf voor de voortplanting geschikt zou worden.

Zooals gezegd, had WEISMANN over deugdelijker gegevens te beschikken, dan zijn voornaamste voorganger Galton. Dat had dan ook tengevolge, dat hij zijn theorie niet alleen beter kon grondvesten, maar ook verder kon uitwerken. De gevallen, waarin de vorming der toekomstige voortplantingscellen direct uit de bevruchte eicel kon worden vastgesteld, waren zeldzaam (Dipteren); daarom ging WeismanN een stap terug van de stirp-leer en meende, dat ook aan enkele somatische cellen zoo nu en dan kiemplasma, bevattend alle erfelijke eigenschappen van het organisme, meegegeven werd. „Wenn die Keimzellen aber auch nur wenige Zellgenerationen später sich abspalten, so ist der postulirte Zusammenhang von elterlicher and kindlicher Keimzellen unterbrochen, denn eine Embryonalzelle, deren Nachkommen nur zum Theil Keimzellen werden, zum andern Theil aber somatische Zellen, kann unmöglich die Natur einer Keimzelle besitzen, ihr Idioplasma kann dem der elterlichen Keimzelle nicht gleich sein. Ein Zusammenhang zwischen Keimsubstanz des Elters und des Kindes, ist auch hier nur dann herzustellen, wenn man eine Beimischung unveränderten Keimplasmas zu dem somatischen Kernplasma gewisser Zellenfolgen zugibt." 
(1885. p. 56). Dat doet echter aan de kontinuïteit van het kiemplasma geen afbreuk; de doorloopende keten is er, en dat is het principieele punt.

Waar GaLToN zich nog zeer vaag uitliet over de samenstelling en de localisatie der stirp, kon WeIsmanN verder gaan; het was door het werk en de beschouwingen van O. Hertwig, Strasburger en hemzelf wel als zeer aannemelijk vastgesteld, dat de kern in de kiemcel de bewaarplaats van dit kiemplasma was, terwijl ook de inwendige structuur van den kern, de chromosomen met hun aanhang toen bekend begonnen te worden. Het is WeISMaNN's groote verdienste, dat hij deze gegevens naar hun beteekenis heeft weten te verwerken; dit stelde hem in staat een tot in details doorgevoerde theorie op te stellen. In 1892 geeft WEISMANN die theorie voor het eerst in het licht; een uitvoerig werk, uitsluitend aan het kiemplasma en zijn beteekenis voor de erfelijkheid gewijd. In het kort komt het door hem geconstrueerde gebouw van den erfelijken grondslag der lichaamseigenschappen hierop neer. Het door NaEGELI zoogenoemde idioplasma, het substraat van alle erfelijke eigenschappen in de voortplantingscel, is volgens WEISMANN gezeteld in de chromosomen; hij had reeds vroeger voorgesteld, die chromosomen niet zoodanig, maar Idanten te noemen (1891. p. 39). Iedere idant zou nu samengesteld zijn uit een aantal naast elkaar liggende kogelvormige lichaampjes, de Iden, „jene bisher als Mikrosomen bezeichneten Kügelchen, welche bei manchen Thieren, vor Allem bei dem in Hinsicht der Kernstructur bestgekannten Thier, der Ascaris megalocephala, den einzelnen Idanten zusammensetzen." (1892. p. 90). Die Iden zijn weliswaar eenheden ; „eine geschlossene Lebenseinheit mit fester Architektur", maar toch niet enkelvoudig. Hun onderdeelen zijn natuurlijk van meer beperkte beteekenis : iedere cel of cellengroep van het volwassen lichaam is in de Ide vertegenwoordigd door een determinante, op zichzelf gesloten lichaampjes, ongeveer vergelijkbaar met de gemmulae van DARWIN, maar vastliggend in de Ide, niet transporteerbaar. Zooals iedere cel of cellengroep nu nog haar bepaalde eigenschappen bezit, zoo moet voor ieder dezer eigenschappen ook een verantwoordelijk fundament in het kiemplasma aanwezig zijn; ook de determinante is dus niet eenvoudig, maar op haar beurt weer samengesteld uit een groep van definitieve levenseenheden, die door WEISMANN 
biophoren genoemd worden. Zoo is dus iedere idant, ieder chromosoom opgebouwd uit iden; iedere ide bevat determinanten, die voor bepaalde cellen of cellengroepen verantwoordelijk zijn en iedere determinante is weer samengesteld uit groepen van biophoren, die alle een bepaalde eigenschap vertegenwoordigen.

In de richting van de architectuur der erfelijke eigenschappen is WEISMANN's theorie dus heel wat verder uitgewerkt dan die yan GaLTON; ook in ander opzicht is ze daarvan verschillend. GALTON had op grond van zijn statistisch materiaal de erfelijke constitutie van ieder organisme samengesteld uit bijdragen van beide ouders, de vier grootouders, enz. Daarvan is nu bij WEISMANn geen spoor te vinden. Hij had hei voordeel de cytologische bevruchtingsprocessen te kennen en hun beteekenis voor de erfelijkheid in te zien. „Das Wesen der geschlechtlichen Fortpllanzung beruht also auf der Vermischung je zweier individuell verschiedener Vererbungstendenzen, oder materiell gesprochen, auf der Vereinigung zweier Vererbungssubstanzen in der Anlage zu einem Individuum" $(1892$. p. 308). Dat zou nog in de lijn van Galton kunnen liggen, maar Weismann zag terecht in, dat niet alleen de amphimixis, ook de zoogenaamde reductiedeeling, waardoor de voortplantingscellen gevormd worden en waardoor zooals bekend is, het aantal chromosomen weer tot de helft teruggebracht wordt, met de erfelijkheidsverschijnselen in betrekking staat. "Wenn die Idanten während der Ontogenese, also von der befruchteten Eizelle bis zu den Keimzellen des neuen Bion im Wesentlichen dieselben bleiben, dann können wir aus gewissen Vererbungserscheinungen schliessen, dass die Reduction der Ide auf die Hälfte nicht im Voraus bestimmte und immer die gleichen Idgruppen von einander trennt, sondern wechselnde, bald diese, bald jene. Die Folge davon muss sein, dass die Keimzellen ein und desselben Bion ( $=$ organisme) ganz verschiedene Combinationen von Iden enthalten, also auch eine ganz verschiedene Mischung der im Keimplasma der Eltern dieses Bion enthaltenen Anlagen..... Der Erfolg würde eine mässige Verschiedenheit der Keimzellen eines Bion auf ihren Gehalt an Vererbungsanlagen sein. In dem angenommenen Falle von nur vier Kernstäbchen würden nur sechs Combinationen von Idanten möglich sein, also auch nur sechs in Bezug auf Anlagen verschiedener Keimzellen-Arten. Die Zahl der 
möglichen Combinationen wächst nun aber sehr bedeutend, so dass schon bei acht Idanten siebzig Combinationen, bei sechszehn 12,870 möglich werden." (1892. p. 321-322).

Een principieele tegenstelling dus tegenover de door Galton aangenomen gelijkheid in erfelijken aanleg van de door een organisme gevormde voortplantingscellen; een aannemen van de ongelijkheid dier voortplantingscellen tengevolge der reductiedeeling. Het pleit wel zeer voor de geniale-logische denkwijze van August Weismann, dat hij acht jaar vóór de krisis in de erfelijkheidsleer, voor het belangrijke jaar 1900, waarin MENDELS werk opnieuw bekend werd, het principieele van MENDELS wetten reeds herkend heeft. Schitterender bevestiging van deze hypothese, dan het erfelijkheidsonderzoek na 1900 gebracht heeft, had WEISMANN niet kunnen verlangen.

Wel zullen naturrlijk alle details van WeISMaNN's kiemplasmatheorie en haar uitwerking niet juist zijn en zal de door hem opgebouwde constructie der chromosomen niet geheel aanvaard kunnen worden, maar toch moge erop gewezen worden, dat óók voor deze, schijnbaar zoo fantastische en zoo vaak spottend besproken, voorstelling in den laatsten tijd argumenten worden aangevoerd, die het principiëele in WeISMANN's opvattingen schijnen te steunen. Men denke slechts aan Morgan's werk over de localisatie der erfelijke factoren.

Het zal geen nader betoog behoeven, dat WeISManN's kiemplasmatheorie in verband met de door hem aan bevruchting en reductiedeeling toegekende beteekenissen, geen ruimte laat voor epigenetische beschouwingen. Er is dan ook in het tijdvak voor 1900 geen feller bestrijder van de veranderlijkheid der erfelijke eigenschappen onder invloed van levensomstandigheden geweest, dan Weismann. Hij erkent geen enkel bewijs van de „erfelijkheid van verworven eigenschappen" als steekhoudend; hij ontkent deze erfelijkheid ten sterkste en beschouwt daarmee den erfelijken aanleg van een gegeven organisme als onveranderlijk tijdens het leven, slechts onderbroken door "Combinationen" der chromosomen, door de reductiedeeling en de amphimixis. Dáárin ligt het zwaartepunt van WEISMANN's theoretische beschouwingen en daartegen is ook thans nog, na het experimenteele onderzoek der laatste jaren, niets in te brengen. 
Want met het keerpunt der eeuwen is een keerpunt ingetreden in de wijze van behandeling der erfelijkheidsvraagstukken Uit het tijdvak der theoretische beschouwingen, gegrond op waarnemingen, is de erfelijkheidsleer overgegaan in het tijdvak van de controleerbare proefneming. En dit is oorzaak geweest, dat een einde gekomen is aan den tijd, waarin HAECKEL sehrijven kon: "Alle Ansichten, welche darüber aufgestelt und in den folgenden Vererbungstheoriën erörtert sind, beruhen auf reiner Mutmassung und sind - streng genommen - metaphysische Spekulationen".(1911 p. 197). Dat danken we Mendel.

(Ingezonden: 1 Juni 1920).

\section{LITTERATUUR.}

Brooks, W. K., 1883. The law of heredity. A study of the cause of variation, and the origin of living organisms (Baltimore-New York. J. Murphy and Co. Second edition, 1883).

BüTSChLI, O., 1876. Ueber die Bedeutung der Entwicklungsgeschichte für die Stammesgeschichte der Thiere (Jahresber. d. Senckenberg. Ges. zu Frankfurt a. M. 1876. p. 66.)

DarwIN, C., 1859. On the origin of species by means of natural selection (London, J. Murray, 1859. Second edition, 1860).

DARWIN, C., 1868. The variation of animals and plants under domestication. (London, J. Murray, 1868. 2 dln. Second edition, 1888).

DelaGe, Y., 1895. La structure du protoplasma et les théories sur l'hérédité et les grands problèmes de la biologie générale (Paris, Reinwald et Cie. 1895).

Galton, F., 1869. Hereditary genius. An inquiry into its laws and consequences. (London, Macmillan, 1869. Second edition, reprinted 1914).

Galton, F., 1871. Experiments in pangenesis by breeding from rabbits of $a$ pure variety, into whose circulation blood taken from other varieties had previously been largely transfused. (Proceed. Royal Soc. XIX. 1870. p. $393-410)$.

Galto F., 1876. A theory of heredity. (Journal Anthropol.-Institute London. V. 1876. p. 329-348. Revue Scientifique 2me Série X. 1876. p. 198-205).

Galton, F., 1877. Typical laws of heredity. (Proc. Royal Institution. London VIII p. $282-301$. Nature 1877. p. $492-495,512-514,532-533$. Revue Scientifique 2me Série. XIII. 1877. p. 385-394).

Galton, F., 1889. Natural inheritance (London, Macmillan, 1889).

Galton, F., 1897. A new law of heredity (Nature LVI. 1897. p. 235-237). 
Galton, F., 1897. The average contribution of each several ancestor to the total heritage of the offspring. (Proc. Roy. Soc. London. LXI. 1897. p. $401-413$ ).

Galton, F., 1898. A diagram of heredity (illustrating the "Ancestral Law"). (Nature LVII. 1898, p. 293).

Galton, F., 1908. Memories of my life (London, Methuen and Co., 1908). Haeckel, E., 1876. Die Perigenesis der Plastidule oder die Wellenzeugung der Lebenstheilchen. Ein Versuch zur mechanischen Erklärung der elementaren Lebensvorgänge. (Berlin, G. Reimer, 1876).

HAECKEL, E., 1911. Natürliche Schöpfungsgeschichte (Elfte Auflage. Berlin, G. Reimer, 1911).

HOFACK ER, J. D., 1828. Ueber die Eigenschaften, welche sich bei Menschen und Thieren von den Eltern auf die Nachkommen vererben, mitbesonderer Rücksicht auf die Pferdezucht. (Täbingen, C. F. Osiander, 1828).

JAEGER, G., 1878. Lehrbuch der allgemeinen Zoologie (Leipzig, 1878).

Johannsen, W., 1917a. Arvelighed i historisk og experimentel Belysning (Andet oplag. Kjöbenhavn-Kristiania. Gyldendalske Boghandel, 1917).

Johannsen, W., 1917b. Die Vererbungslehre bei Aristoteles und Hippokrates im Lichte heutiger Forschung (Die Naturwissenschaften. V. 1917. p. 389-397).

Lucas, P., 1847. Traité philosophique de l'héredité naturelle dans les états de santé et de maladie du système nerveux (Paris, 1847).

MaY, W., 1917. Antike Vererbungstheorien (Naturwiss. Wochenschr. N. F. XVI. 1917. p. 9-10).

Meckel, J. F., 1812. Handbuch der pathologischen Anatomie (Leipzig, 1812).

NaEgeli, C., 1884. Mechanisch-physiologische Theorie der Abstammungslebre (München-Leipzig, R. Oldenbourg, 1884).

Nussbaum, M., 1880. Die Differenzirung des Geschlechts im Tierreich (Archiv f. mikrosk. Anatomie. XVIII. 1880. p. 1-121).

SPencer, H., 1864. The principles of biology (London, Williams and Norgate, 1864. Revised and enlarged edition 1898).

VRIES, H. DE, 1889. Intracelluläre Pangenesis. (Jena, Fischer, 1889).

Weismann, A., 1883. Ueber die Vererbung. Ein Vortrag (Jena, Fischer, 1883. Ook in: Aufsätze über Vererbung und verwandte biologische Fragen. Jena, Fischer, 1892. p. 73-122).

Weismann, A., 1885. Die Continuität des Keimplasmas als Grundlage einer Theorie der Vererbung. (Jena, Fischer, 1885. Ook in: Aufsätze etc. 1892. p. 191-302).

Weismann, A., 1891. Amphimixis oder die Vermischung der Individuen. (Jena, Fischer, 1891. Ook in : Aufsätze etc., 1892. p. 673-826).

Weismann, A., 1892. Das Keimplasma. Eine Theorie der Vererbung. (Jena, Fischer, 1892). 